City University of New York (CUNY)

CUNY Academic Works

\title{
Anti-Minority Riots in Unified Germany: Cultural Conflicts and Mischanneled Political Participation
}

Roger Karapin

CUNY Hunter College

\section{How does access to this work benefit you? Let us know!}

More information about this work at: https://academicworks.cuny.edu/hc_pubs/656

Discover additional works at: https://academicworks.cuny.edu

This work is made publicly available by the City University of New York (CUNY).

Contact: AcademicWorks@cuny.edu 
Published as Roger Karapin, "Anti-Minority Riots in Unified Germany: Cultural Conflicts and Mischanneled Political Participation," Comparative Politics 34 (January 2002), pp. 147-67.

Anti-Minority Riots in Unified Germany:

Cultural Conflicts and Mischanneled Political Participation ${ }^{1}$

Roger Karapin

June 2001

\begin{abstract}
Anti-foreigner riots in eastern Germany in the early 1990s have usually been explained by ethnonationalism or racism, ethnic competition for scarce resources, and opportunistic political elites. If anti-minority riots are analyzed as a distinct phenomenon with a cross-sectional approach, local political processes emerge as more important causes. Cultural conflicts, the channeling of mobilization from nonviolent into violent forms, local political opportunities for success, and mobilization by social movement organizations convert ethnic conflict and violence into riots. A comparison of riot and non-riot localities in eastern Germany supports this argument.
\end{abstract}

Two large anti-foreigner riots in eastern Germany (at Hoyerswerda in September 1991 and at Rostock in August 1992) created a political sensation, attracting far more attention, outcry, and veiled approval from political leaders than two thousand smaller assaults on foreigners which took place across unified Germany during those two years. Explanations of the riots in unified Germany, and also much of the theoretical work on anti-minority riots in other democratic systems, have focused on three sets of causes: ethnonationalism, insecure ethnic identities, and racism; poverty, inequality, and competition between ethnic groups for scarce resources; and political elites stirring up enmity to mobilize groups along ethnic lines. ${ }^{2}$

These analyses are flawed in two ways, which this article addresses. First, they often treat riots as simply the most extreme manifestation of ethnic conflict and violence, rather than as a qualitatitively different phenomenon. But because of their nature and their political significance, 
anti-minority riots should be analyzed separately from other forms of ethnic conflict. ${ }^{3}$ Of course, violence is distinct from other forms of conflict in that it requires risky behavior, usually involves some confrontation with police, and has terrible consequences for its targets. Moreover, antiminority riots are a quite distinct form of ethnic violence. By anti-minority riots, I mean sustained physical attacks on members of a subordinate ethnic minority group by large numbers of people who belong to the dominant ethnic group, are motivated by ethnic or racial animosity, and are not agents of the state. ${ }^{4}$ Hence, anti-minority riots differ from commodity riots by minority group members against property and police (often called "race riots"), and from hit-andrun assaults by small groups against minority group members (racist violence).

Moreover, anti-minority riots in democratic settings have unusual political significance. Such riots often attract large numbers of approving spectators who are adults and are not evidently members of extreme nationalist or racist organizations. Hence politicians and news media may interpret the riots as indicators of widespread and salient ethnic antagonisms. Therefore, political reactions to anti-minority riots can lead to major policy shifts, such as immigration restrictions or limitations on minority rights. Furthermore, because of the scale of the mobilization, other perpetrators may try to imitate the attacks. At Hoyerswerda and Rostock, crowds of many hundreds or several thousands of adults gathered to watch the skinheads attack the foreigners' housing, sometimes cheering on the attackers and chanting anti-foreigner slogans. The riots were heavily covered by television and other news media, and they touched off large numbers of violent attacks against foreigners across unified Germany and fueled a national-level political debate on the right to political asylum; ultimately, they helped lead to a constitutional amendment sharply restricting asylum rights in May $1993 .^{5}$ 
Second, most of the work cited above is based on analyses of riot cases and ignores cases where riots did not occur. ${ }^{6}$ Taken together, these two flaws have led to an overemphasis on variables, such as racism and poverty, which are much more common than anti-minority rioting is. Such factors do not help explain why riots rather than other forms of ethnic conflict occur. Even within countries, regions, and historical periods where ethnic riots occur, many localities do not experience riots, although small-scale racist violence may occur there. For example, in Britain, the number of racially motivated attacks against non-white people ranged between about 1200 to 2300 annually in the late 1980 s and early '90s, but Britain has not had any anti-black rioting since $1965 .^{7}$ In Germany, skinheads and neo-Nazis carried out 1100 arson attacks against foreigners' housing and property between 1990 and 1992, but only six major riots against foreigners occurred during those three years, all in eastern German communities. ${ }^{8}$

In this article, I aim to help identify the additional conditions which tend to turn ethnic conflicts, including small-scale violence, into anti-minority riots. To that end, I first draw on theoretical work which specifically addresses anti-minority riots in order to elaborate plausible hypotheses, in the next section. The bulk of the article then analyzes contrasting cases in eastern Germany soon after the unification of East and West Germany. I compare Hoyerswerda, and to a lesser extent Rostock, with Riesa, an eastern German locality which experienced no rioting and indeed little anti-foreigner violence in the early 1990s.

My main argument is that if anti-minority riots are analyzed as a distinct phenomenon and via a cross-sectional approach, local political processes appear to be important causes of the riots, while ethnic competition and national political processes are evidently less important. In particular, the following factors which tend to convert lower-level ethnic conflict and ethnic 
violence into major riots: cultural conflicts, the channeling of mobilization away from nonviolent forms and into violent forms, the local provision of political opportunities for success, and mobilization by social-movement organizations. In the conclusions, I suggest that these local processes can help explain why riots are more likely in two circumstances: after ethnic groups migrate to new localities in democratic countries, and while an ethnically diverse country experiences a chaotic transition to democracy.

\section{Theoretical Approaches and Hypotheses}

Racist and Xenophobic Attitudes Although xenophobia is a popular explanation of the German riots, hostile attitudes toward minorities in fact are not closely related to rioting. Negative (even racist) attitudes toward foreigners have been very widespread in Western European countries in the 1980s and '90s, yet only Germany had anti-immigrant riots in that period. ${ }^{9}$ Moreover, eastern Germany in the early 1990s did not have generally higher levels of xenophobia than western Germany, but the riots occurred only in the east, where rates of antiforeigner violence were also much higher. ${ }^{10}$ Racism or xenophobia are obviously necessary conditions for anti-minority riots, but unfortunately the quantity of such attitudes sufficient to produce riots seems low enough to be widely available. Because xenophobic attitudes comprise a poor explanatory factor of cross-sectional differences, and because attitudinal data is basically nonexistent at the local level in Germany, I will not pursue this hypothesis further.

Ethnic Competition and Economic Grievances Ethnic-competition theory has been widely 
applied to ethnic conflict, including anti-minority riots. ${ }^{11}$ The theory holds that competition for scarce resources between dominant and subordinate ethnic groups, e.g. due to increases in immigration or unemployment, leads to riots and other violence as the dominant group tries to protect or advance its material interests. This might account for the eastern German riots, since eastern Germany experienced massive increases in unemployment after unification and small inflows of foreigners in the early '90s. Hence the first hypothesis is that anti-minority riots will take place in locations and at times with unusually high or rising unemployment rates and immigrant population shares, since in those areas the competition for jobs and housing is most intense.

Cultural Conflicts Park has argued that a minority group's differences in appearance and in culturally rooted customs initially produce an apprehensive, defensive reaction from native populations, in places where the natives have little experience of interacting with ethnic strangers. ${ }^{12}$ Building on this idea, Husbands suggests that initial interactions between ethnic groups are prone to spark conflicts which arise from different customs relating to noise, sanitation, dress, sexual relations, religious practices, etc., and that these conflicts can lead to territorial riots between ethnic groups. ${ }^{13}$ Riots are especially likely when actual differences in cultural practices become exaggerated by racist or ethnonationalist stereotypes and rumors. Therefore, the second hypothesis is that cultural conflicts spurred by the relatively recent arrival of new ethnic groups become acute in the period before the beginning of rioting, and that largescale violence grows out of these cultural conflicts.

The cultural-conflicts theory suggests a link between immigration and rioting in eastern 
Germany which is different from that proposed by ethnic-competition theory. In both cultural conflicts and ethnic competition, members of the dominant group are offended or threatened by what they perceive as efforts by the minority group to improve its position at the expense of the dominant group. ${ }^{14}$ But in cultural conflicts, scarce economic resources are not at stake, and the sources of conflict might be removed through communication and experience.

\section{Facilitation and Channeling of Political Participation Anti-minority rioting can be} interpreted as rational political activity. ${ }^{15}$ Rioters may aim to drive members of the minority group out of the area, to inflict enough harm to deter others from coming, or to increase the power position of the dominant group relative to the minority within the locality. As they pursue their goals, potential participants in riots are best seen as "challengers," since they lack routine access to authoritative decision making; they contrast with political elites such as government officials, party leaders, and interest-group leaders, who enjoy such access. ${ }^{16}$ As challengers, potential rioters are sensitive to political opportunity structures which in turn can be strongly influenced by political elites. ${ }^{17}$ One main dimension of political opportunity structures is "facilitation," i.e. lowering the costs and risks of taking certain kinds of political actions relative to prior conditions and relative to other actions. ${ }^{18}$ Patterns of facilitation can explain why riots occur, rather than merely smaller-scale violence, nonviolent protests, lobbying, or voting on behalf of the anti-minority cause.

Indeed, bias, inaction, and vacillation by police have been recognized as crucial factors in all kinds of riots. ${ }^{19}$ But elites' reactions to violence comprise only half of the facilitation process; the other half consists of low-cost channels for nonviolent mobilization, such as anti-minority 
voting, contacting officials, and attending neighborhood meetings. ${ }^{20}$ Such channels have different effects on instigators of violence, who engage in severe and provocative violence, and on supporters, who shout and cheer, chant slogans, interfere with police, or merely serve as sympathetic or interested audience members. When nonviolent channels are available, potential supporters of violence will tend to use them; hence, even if instigators carry out violence against ethnic minorities, these attacks are unlikely to draw the crowds of supporters necessary to create riots.

Therefore, the third hypothesis is that anti-minority rioting is much more likely when political elites and institutions channel political participation by dominant-group members in two ways: by failing to provide low-cost, nonviolent channels for mobilization on grievances concerning the minority group, or only channels which obviously are ineffective; and by reducing the costs and risks which the perpetrators of anti-minority violence experience, especially through police actions and inaction.

Political Opportunities: National and Subnational The other main dimension of politicalopportunity structures concerns "opportunities," i.e. the probability that action by challengers will help them achieve an outcome they desire, such as driving out the minority group. ${ }^{21}$ Opportunities will appear to be greater if political elites publicly support anti-minority positions, suggesting that further anti-minority mobilization, including riots, might tip the balance in favor of anti-minority decisions by government. For example, opportunities rise if political elites engage in public debates about immigration-control policies, suggest that ethnic minorities might be removed from a locality, give a hearing or other support to anti-minority groups, or make 
public statements hostile to the minority group. Many authors have argued that national politicians encouraged the 1990 s riots in Germany by advocating restrictions on asylum rights. ${ }^{22}$ Therefore, the fourth hypothesis is that anti-minority riots occur only after national-level political elites show, via public statements or actions, that they share potential rioters' opposition to the presence of the ethnic minority.

However, subnational elites may also be important in creating anti-minority opportunities. $^{23}$ Local government is relatively easily accessible to groups which are weakly organized and poor in material resources; local politicians are often the first to respond to emerging issues, and they may be more willing than national politicians to make anti-immigrant or racist statements. ${ }^{24}$ Moreover, in Germany as in many countries, regional and local authorities have substantial power over where minority populations are housed. Therefore, the fifth hypothesis is that anti-minority riots occur only after subnational political elites increase apparent opportunities by signaling that they share potential rioters' opposition to the presence of the ethnic minority. Where subnational officials control the police, as in Germany, such signals may also encourage rioting by shifting the pattern of facilitation, as posited in the third hypothesis. ${ }^{25}$

Social-Movement Organizations Although anti-minority riots are sparked by a wide range of triggering events, ${ }^{26}$ riots do not necessarily begin and develop spontaneously, without organization. Rather, social-movement organizations may create triggering events or instigate broader mobilizations on the basis of events created by others; organizations help solve the freerider problem of collective action. "Social-movement organizations" here refers to either formal organizations or loosely organized groups which undertake a challenge. ${ }^{27}$ Even small and 
informally organized social-movement groups can induce their members to undertake risky action by socially rewarding and sanctioning them. ${ }^{28}$ Studies of skinhead groups have noted that their members attain important intangible benefits such as a sense of belonging in exchange for undertaking risky actions. $^{29}$

Social-movement organizations relevant to anti-minority riots have two qualities: they are opposed to ethnic minorities and they have offensive violence in their collective-action repertoires. Examples of youth groups involved in anti-minority riots include athletic clubs and gangs in the 1919 anti-black riots in Chicago and Teddy boys in the 1950s anti-black riots in Britain; examples of far-right organizations include right-wing groups in the 1905 anti-Jewish riots in Odessa and the White Defence League in the 1958 Notting Hill, London riots. ${ }^{30}$ Therefore, the sixth hypothesis is that violent, anti-minority social-movement organizations are present in riot localities and an increase in their activities contributes to anti-minority riots.

Immigration and the Rise of Anti-Minority Violence in Unified Germany Just before and after unification in 1990, Germany experienced a sharp increase in both immigration and violence against its ethnic minorities, who seldom possess German citizenship and are typically labelled "foreigners." ${ }^{31}$ Between 1988 and 1993, the foreign population of Germany increased by 2.4 million, including 1.4 million people from Eastern Europe, Asia, and Africa who applied for political asylum and 200,000 who were living in East Germany before unification. In addition, about 1.6 million ethnic Germans "resettlers" arrived from Eastern Europe, the Soviet Union, and its successor states in this period, with constitutional rights to automatic German citizenship; they were immediately classified as "German." ${ }^{32}$ Asylum seekers were attracted by rights 
embedded in the German constitution and courts, which allowed them to remain in the country for many years while their cases were decided. ${ }^{33}$ Skinheads, other youths, and neo-Nazis carried out an average of 400 arson attacks and 1300 other violent crimes against foreigners per year from 1991 to 1993, about a ten-fold increase compared with the 1980s; attacks dropped sharply after 1993, as did immigration. ${ }^{34}$ The main targets of attacks were asylum seekers, who were distributed to the eastern states beginning in 1991. In the east, victims of anti-minority violence after unification also included foreign laborers from Africa and Vietnam, who had been recruited by the East German government and were to remain in the eastern part of unified Germany until their multi-year labor contracts expired. By far the most important attacks were the riots at Hoyerswerda and Rostock. The political significance of those two riots, noted above, reflected their duration, intensity, and number of participants, which made them the most serious antiminority attacks in post-war Germany. ${ }^{35}$

To test the hypotheses developed above, I focus on Hoyerswerda and Riesa Counties. Both localities lie within the eastern state of Saxony, which had the third-highest per-capita rate of anti-foreigner violence among all German states in $1991 .^{36}$ Yet over half of Saxony's fiftyfour counties and independent cities had no publicly reported attacks against the dwellings of foreign workers and asylum seekers during the peak periods of violence in the state. ${ }^{37}$ Among the low-violence counties, I choose Riesa County as a contrasting case of low anti-foreigner violence which was matched with Hoyerswerda on many key dimensions. Compared with other Saxon localities in the early '90s, these two localities both had a medium degree of urbanization, similar unemployment rates, a medium number of foreign residents, a relatively large group of asylum seekers, a relatively large group of right-wing skinheads, similar levels of skinhead 
action, and local government effectively dominated by a grand coalition of the Christian Democratic Union (CDU) and Social Democratic Party (SPD). ${ }^{38}$

In combining low violence with these structural features, Riesa is representative of many other local cases in eastern Germany. Within Saxony, there was little anti-foreigner violence during the period studied in 10 out of the 19 localities (53\%) which had large skinhead groups, in 16 out of the 29 localities (55\%) which had stable or increasing shares of foreigners, and in 13 out of the 22 localities (59\%) which housed at least 50 asylum seekers by the end of $1993 .^{39}$ By controlling for minority populations, unemployment, and skinhead organization, the Hoyerswerda-Riesa comparison permits focusing on the potential effects of cultural conflicts, the channeling of participation, the facilitation of violence, and local political opportunities. The hypotheses regarding ethnic competition and national opportunities will be tested by examining evidence internal to each case, by comparing riot cases to the rest of eastern Germany, and by analyzing temporal developments.

\section{Hoyerswerda vs. Riesa: Riots vs. Peaceful Ethnic Relations}

Foreigners and Anti-Foreigner Violence in Hoyerswerda and Riesa Hoyerswerda and Riesa were similar in many respects. Foreign laborers, mainly from Mozambique and Vietnam, had lived in Hoyerswerda County since the early 1980s; they worked mainly in the locally dominant coal industry, on three-year labor contracts. In addition, about 230 asylum seekers from over twenty countries, principally Romania, the former Yugoslavia, and Ghana, were 
moved into the city of Hoyerswerda by Saxon and local authorities in Spring $1991{ }^{40}$ Riesa in 1991 was an industrial county dependent on a few large employers in the steel industry. In Riesa, too, the East German government had brought hundreds of foreign workers to Riesa from Mozambique, Vietnam, and Angola. During 1991, 260 asylum seekers from at least 12 countries arrived in Riesa County, as did 200 ethnic German resettlers. ${ }^{41}$

On 17 September 1991, right-wing skinheads began sustained, large-scale attacks on foreigners in Hoyerswerda. Attacks continued for four days against the foreign workers and were followed by three days of crowds massing outside the asylum seekers' housing, which was in a different neighborhood about three kilometers distant. ${ }^{42}$ The attackers used bottles, chains, clubs, baseball bats, and molotov cocktails, threatened to burn down the building, and said they would continue their attacks until the foreigners had left. At the height of the rioting, 50-100 youths attacked the foreigners' housing while crowds of 500 or more adults watched, shouted slogans, cheered, and hindered police. The attacks against the foreign workers continued until police massed outside their housing, and the attacks against the asylum seekers continued until authorities removed the victims from Hoyerswerda County to undisclosed locations in Saxony.

The violence was directed mainly against the foreign workers, whose housing was heavily attacked night after night, while the actions against the asylum seekers took the form of a siege and threats rather than heavy violence. Nonetheless, the Hoyerswerda riots strengthened national political forces which sought to restrict asylum rights. The national leaders of the CDU and the Christian Social Union (CSU), who governed in Bonn in a coalition with the liberal Free Democratic Party (FDP), used the riots to try to pressure the opposition SPD to accept a constitutional amendment aimed at reducing asylum applications; ${ }^{43}$ up to the present day, 
"Hoyerswerda" is a widely recognized symbol for the popular rejection of asylum seekers in Germany.

Riesa had an active skinhead group of 20-35 youths, yet through the end of 1993, the Riesa skinheads did not carry out a single concerted attack against the residences of asylum seekers or other foreigners living in the county. Skinheads tried to attack Riesa's asylum hostel several times, but each attempt remained unsupported by neighbors, was aborted, and damaged little property. For example, in September 1992, in the wake of the Rostock riots and in the middle of a large wave of attacks on foreigners' hostels throughout Germany, 30-40 youths from the residential area around the Riesa County asylum hostel assembled outside it. They were met by a large police presence, and after police and youths waited for two hours, the group dissolved and the youths went home. ${ }^{44}$

\section{Ethnic Competition and Violence in Eastern Germany The hypothesis concerning ethnic} competition for material resources receives little support from these cases. True, the antiforeigner riots in the eastern states occurred during a major economic crisis there, as the introduction of West German currency caused industrial production to drop by about two thirds during the second half of 1990; the real rate of unemployment, including those out of work and on "short hours," reached about $29 \%$ in July $1991 .^{45}$ The subjective sense of economic insecurity was intense for many eastern Germans, who had experienced more than forty years of a command economy with guaranteed employment.

But the anti-minority riots did not occur in the most objectively distressed areas of eastern

Germany. ${ }^{46}$ Hoyerswerda County's unemployment rate was several percentage points below the 
average for Saxony, and youth unemployment there actually dropped by a third from July through October 1991; Rostock's unemployment rate was also below average. ${ }^{47}$ Furthermore, although unemployment was rising, there was actually very little job competition between the foreigners and the native population in Hoyerswerda. The foreign workers had the most dangerous or dirtiest jobs, which Germans normally were unwilling to take, e.g. working around phenol in the local coal processing plant. ${ }^{48}$ Asylum seekers in Germany were completely banned from employment until July 1991 and after then could receive work permits only if it could be shown that no European Community citizen could do the job; in Hoyerswerda, asylum seekers were not even required to do community work in exchange for social assistance, since local officials wanted to reserve any such work opportunities for Germans. ${ }^{49}$ "Foreigners take our jobs away" was a frequent complaint of Hoyerswerda residents, which shows that perceived grievances may be necessary for anti-minority riots, but also that subjective perceptions of ethnic competition can be produced in the absence of objective competition.

Finally, German residents were not threatened by large numbers of ethnic minorities. Even after two years of immigration, at the end of 1992 the foreign population share in eastern Germany was only $2.8 \%$, compared with $9.4 \%$ in the relatively low-violence western part of the country. The foreign population of Hoyerswerda actually declined during the nine months before the riots; it was 36\% lower in the city in August than it had been at the start of 1991, because more foreign workers went home than asylum seekers arrived. ${ }^{50}$ Nor were foreigners competing with Germans for apartments in Hoyerswerda, which had a housing surplus due to an overall decline in population. Indeed, both the foreign workers and the asylum seekers in Hoyerswerda were living in buildings which had been occupied for years by foreign laborers, not by Germans. 
In housing, the potential for ethnic competition was actually greater in Riesa, where the total number of foreigners was stable during 1991 and housing was scarce, with 3500 households seeking apartments that year. ${ }^{51}$

Cultural Conflicts in Eastern Germany The differences in violence between the two cases are much more closely related to differences in cultural conflicts. In the city of Hoyerswerda, the presence of small numbers of foreigners concentrated in the densely populated Neustadt section led to cultural conflicts, mainly between the foreigners and their immediate neighbors. Smallscale conflicts between Germans and the foreign workers had occurred in the 1980s, but larger conflicts were suppressed until after the East German state collapsed. ${ }^{52}$ Civil liberties were effectively introduced in 1989-90, as hard-line Communist Party chair Erich Honecker resigned in October 1989, the police and secret police stopped enforcing communist-era discipline, and competitive national elections were held in March 1990.

Suddenly, eastern Germans' dissatisfaction with foreigners could be expressed much more freely; in contrast, the foreigners' views about the cultural practices of their German neighbors did not become the topic of political conflicts and newspaper reporting, which reflects the foreigners' much weaker social and political position. The main complaints by Germans in Hoyerswerda concerned late-night noise, garbage, and reckless driving by foreigners; other complaints concerned sexual relations between foreign men and German girls or young women. ${ }^{53}$ The foreign workers and asylum seekers were housed in groups of over one hundred, which concentrated the behaviors that many Germans found offensive, threatening, or incomprehensible. The problems were intensified by high-density housing; some Germans lived 
in the same twelve-story apartment complex occupied by the foreign workers, and many others lived in adjoining or immediately neighboring buildings. Conflicts over noise were exacerbated by the fact that the Germans were on daily work schedules, while many foreign laborers worked late shifts and the asylum seekers had much time on their hands since they were not permitted to work at all.

The Hoyerswerda riots were closely related to these cultural clashes. In September 1991, as most foreign workers were preparing to leave for their countries of origin, noise from their farewell party, described as especially loud, bothered their German neighbors. A few days later, these neighbors formed the bulk of the crowds which participated in the first nights of rioting. Moreover, when skinheads attacked Vietnamese at the start of the September 1991 riots, Mozambicans counter-attacked by throwing objects from the roof of their building. The sight of black men fighting German youths frightened or outraged some Germans, and helped to draw large crowds sympathetic to the skinheads who attacked the Africans.

The cultural conflicts between asylum seekers and their neighbors in Hoyerswerda were exacerbated by public policies adopted by both the East German regime and by the Federal Republic of Germany. In East Germany, the state actively discouraged and prevented social interaction between foreign workers and the German population. ${ }^{54}$ Therefore, conflicts between Germans and foreigners were not tempered by friendships or channeled into nonviolent forms along pre-existing lines of communication. Furthermore, when asylum seekers arrived in Hoyerswerda, local officials treated asylum seekers according to policies adopted by West Germany's state and federal governments during the 1980s: the ban on employment, a requirement that asylum seekers live in hostels and stay within the county to which they were 
assigned, and inadequate personnel to mediate between them and their German neighbors. ${ }^{55}$ These policies were intended to deter asylum seekers from coming to Germany, but they also exacerbated cultural conflicts by concentrating the foreigners and limiting their normal economic and social contacts with Germans. Together with the decision to transfer asylum seekers to many small localities in eastern Germany, these policies, set the stage for widespread cultural conflicts.

In a similar way, the intense riots at Rostock grew out of cultural conflicts between several hundred asylum seekers, mainly Romas, and their German neighbors. The Rostock asylum hostel was badly overcrowded, forcing asylum seekers to camp on the lawns outside the building and leading their German neighbors to complain repeatedly about noise, dirt, begging, and gambling on the street. ${ }^{56}$ Residents' complaints eventually led to an anonymous call in the local newspapers for a demonstration against asylum seekers. The riots began the next day when a crowd of 150 gathered outside the hostel. ${ }^{57}$

In Riesa, cultural conflicts between Germans and foreigners were much more limited. Conflicts did occur over the theft of car radios later found in the asylum hostel, begging by gypsy children in the streets, and illegal trading by Vietnamese. ${ }^{58}$ But in Riesa the conflicts between Germans and asylum seekers did not become matters of sustained public attention, in which the skinheads could have intervened and found a sympathetic adult German audience. One reason is that county officials housed the asylum seekers in former workers' barracks on the edge of Zeithain, a town of 4500 people about five kilometers from the county's largest city; unlike in Hoyerswerda, large numbers of German neighbors did not immediately adjoin the asylum seekers' building. Although Riesa County was also home to over 600 other foreigners, mainly laborers, the only conflicts between them and Germans were two small-scale attacks by 
skinheads against foreign businesses. ${ }^{59}$

\section{The Channeling and Mischanneling of Political Participation These two cases strongly} support the channeling hypothesis. In Hoyerswerda at the time of the 1991 riots, citizenparticipation mechanisms, such as public hearings, public dialogues between citizens and officials, and citizen attendance of city or county council meetings, were very limited. During all of 1991, Hoyerswerda residents were publicly invited to only four meetings. ${ }^{60}$ In late August, however, city councilors hastily called a public forum to deal with conflicts surrounding the asylum seekers' hostel. This heated, two-hour meeting began to create nonviolent channels through which the asylum seekers' neighbors could participate. Officials made some concessions and promised another meeting with residents; moreover, they advised the neighbors on how to report legal violations such as excessive noise to the authorities. After unification, these violations needed to be reported to the Town Clerk's Office (Ordnungsamt) rather than to the police, which was the practice under the communist government. Before the August meeting, most residents of Hoyerswerda did not understand the new process, or why their complaints to the police led to no action. ${ }^{61}$

By contrast, there was no public meeting for the Germans who lived near the foreign workers, and those Germans did not learn about how to make more effective complaints about their non-German neighbors. These differences in political participation and political information can explain why the rioting was much more intense against the foreign workers in Hoyerswerda. ${ }^{62}$ Another difference is that the conflicts between the foreign workers and their German neighbors went back at least several years, compared with several months of conflicts 
between the asylum seekers and their neighbors.

While nonviolent channels were extremely limited or nonexistent, political participation was channeled into violence in Hoyerswerda during 1991. Skinheads learned that they could attack foreigners nearly with impunity, and hence many adult German residents came to see the skinheads' methods as the most reliable ones for "doing something about the foreigners." ${ }^{63}$ Moreover, skinheads gained visibility and a degree of legitimacy through vigilante activities which were tolerated by the police and greeted by the population. While crime was rapidly rising during Winter 1990-91, a neo-Nazi group of about ten skinheads ("Neue Deutsche Ordnung") was formed. The group patrolled Hoyerswerda streets, offered fearful women rides home late at night, took action against burglars and auto thieves, and sometimes handed their victims over to the police. $^{64}$

Crucially, Hoyerswerda police did not seriously interfere with the assault against the foreign workers' housing on the first few nights of rioting in September. A force level of one hundred police officers was not reached until the third night of rioting, the foreign workers' housing was not cordoned off until the fourth day, and eyewitnesses reported that the police were passive and scared. Deliberate police passivity was even more evident in the Rostock riots, where police forces and equipment were adequate in size, yet police inaction during the first three nights of rioting was remarkable. Eventually police forces withdrew completely for two hours, allowing seventy youths to set on fire a building housing over 100 foreign workers, all of whom miraculously escaped over the rooftops. ${ }^{65}$

The extreme failure of policing in Hoyerswerda was due in part to difficulties caused by the collapse of the communist system and the unification process. As the old regime's secret 
police were disbanded, the regular local police forces proved to be inadequately trained and equipped to deal with crime in a society no longer controlled by the communist Socialist Unity Party. ${ }^{66}$ However, the police failure in Hoyerswerda was due also to the lack of a will to intervene decisively against skinheads and crowds of Germans, and on behalf of foreigners. While the lack of will was apparent at all levels, the Saxony Interior Minister, Rudolf Krause (CDU), played a key role by frequently downplaying right-wing violence and showing obvious disinterest in protecting foreigners. In Hoyerswerda, he announced that he wanted to avoid a large police action, and that asylum seekers should be fenced in or evacuated to an army building in a neighboring county. ${ }^{67}$

In Riesa, by contrast, cultural conflicts did not flare up dramatically in part because political participation was channeled into nonviolent forms. Violence against foreigners was repeatedly and speedily suppressed by the police, while channels for citizen participation in many areas were abundant. As a result, the skinheads pursued other targets, and the other youth and adult citizens of Riesa did not act with major open hostility toward the county's ethnic minorities.

Riesa's police acted decisively against right-wing youth almost every time the latter engaged in violence; in particular, police did not allow skinheads to undertake vigilantism or to dominate the streets during any period. There were seven occasions during 1991 when police prevented rioting by large numbers of right-wing youths. ${ }^{68}$ Police interfered especially with skinhead attacks against foreigners. For example, police turned up with a large force when the asylum hostel was approached by 30-40 hostile youths in September 1992. Unable to act effectively against such a well-defended target, the skinheads tended to seek victims among leftists and punkers in bars and discos, where the police were more reserved and the private 
owners or managers could not maintain order. ${ }^{69}$

Police acted more effectively in Riesa largely because their leaders were interested in combatting right-wing crime and therefore the officers learned how to deal with it much earlier, more quickly, and more thoroughly than the police in Hoyerswerda. The Riesa police experienced the institutional difficulties typical of eastern German police forces, and they confronted high and dramatically increasing general crime rates after unification; Hoyerswerda and Riesa counties had similar crime rates and similarly low rates at which crimes were solved. ${ }^{70}$ But the Riesa police were successful in their priority areas, which included investigating murders (seven out of seven cases were solved in one period) and suppressing crimes by rightwing youth. $^{71}$ The successes of the Riesa police were partly due to the practical, persistent, and remarkably open-minded way they responded to their challenges. Police leaders in Riesa were open and communicative with the press, were willing to admit mistakes, and called on the public for cooperation. $^{72}$

The nonviolent channels of participation in Riesa were as open as the violent ones were blocked. Citizens groups were quite active, and the number of nonviolent demonstrations, strikes, and petitions circulated was about three times as large as in Hoyerswerda. ${ }^{73}$ Furthermore, Riesa officials normally held hearings and discussions on a wide range of local public-policy issues; in 1991, there were 17 political meetings of all kinds in Riesa, four times the number held in Hoyerswerda, with topics such as "the problems of youth in our city" or noise from a disco. These kinds of citizen participation are an indicator of the overall relations between citizens and local authorities. It is likely that any neighbors of the Riesa county asylum hostel who were dissatisfied with the behavior of the hostel's residents would have felt comfortable approaching 
either the county employees managing the hostel, the police, or the elected officials of the town of Zeithain or Riesa County.

National Political Opportunities There is little evidence that the national debate on asylum rights accounts for the timing of the six major anti-minority riots which occurred in eastern Germany from 1990-92. Most obviously, there is little correlation between the debate and the riots. The Hoyerswerda and Rostock riots, the most serious of all these events, occurred during relative lulls in the asylum debate. ${ }^{74}$ There are several other reasons to conclude that national political opportunities had little effect on the Hoyerswerda, Rostock, and other eastern German riots. First, the national asylum debate was relatively unimportant in eastern Germany. For example, the tabloid BILD (Dresden edition) failed to cover the debate at all during the two months prior to the Rostock riots, and the Rostock newspapers also carried few stories. Furthermore, eastern Germans consistently named economic problems as much more important than issues related to foreigners, also in the periods just before the riots. Only $8 \%$ of easterners named asylum as an important problem in September 1991 (compared with 45\% of westerners), and the eastern figure rose to only about $20 \%$ in August 1992, compared with $60-80 \%$ who named unemployment. ${ }^{75}$ Second, a brief riot by skinheads and youth against the foreign workers in Hoyerswerda in May 1990 occurred during a long lull in the national asylum debate. ${ }^{76}$ Third, $^{2}$ if the national debate on asylum were a major cause of the Hoyerswerda riots, the asylum seekers in Hoyerswerda would have been more important targets than they were.

Local Political Opportunities By contrast, local political opportunities for anti-foreigner 
mobilization increased just before the Hoyerswerda and Rostock riots. Local authorities in Hoyerswerda showed tacit support for anti-immigration positions in three ways. First, county and city authorities were passive and inattentive toward the issue of foreigners, although not openly opposed to the minorities. The officials' passivity helped create a political vacuum on the issue, making it easier for the skinheads to assert an issue monopoly during the months leading to the riots. ${ }^{77}$ Second, when local politicians and county administrators did address the issue at the citizens forum a month before the riots, they seemed to opened opportunities for those who wanted to advance the "Foreigners out" agenda. At that meeting, acting mayor Klaus Naumann (SPD) told the angry crowd that he would talk with other officials about possibly moving the asylum seekers and would hold another meeting a month later. ${ }^{78}$ He thereby opened the possibility of getting the asylum seekers out of the neighborhood even as he was trying to channel residents' participation into negotiations and legal channels rather than violence. A similar pattern occurred in Rostock, where a city official, Peter Magdanz (SPD), tried to mediate between disgruntled residents and the wholly unresponsive city and state governments. Although he sought a nonviolent solution, Magdanz's calls to have the asylum hostel moved to another neighborhood probably increased expectations that the asylum seekers could be forced out violently. $^{79}$

Third, two widely reported police actions against foreigners by the Hoyerswerda police strengthened the foreigners-out agenda by creating the impression that someone in authority was finally willing to act against the foreigners. ${ }^{80}$ In particular, in early July 1991, 120 police from several counties conducted a highly publicized raid of Vietnamese cigarette dealers on the Hoyerswerda marketplace, arresting nineteen Vietnamese and one Turk. These arrests seem to 
have influenced the skinheads' choice of targets; two months later, the riots were touched off when eight skinheads attacked a group of Vietnamese traders on the street where they normally sold untaxed cigarettes.

By contrast, local opportunities for skinheads to influence in-migration by foreigners were quite small in Riesa, as official statements and actions were mainly educational and proforeigner. When asylum seekers arrived, Riesa's authorities initiated a small information campaign, designed to reduce prejudices and gain the natives' acceptance. During 1991-93, authorities held three meetings with German residents about asylum seekers (including a heated five-hour discussion with soldiers at the Zeithain army base) and caused several informative articles about asylum seekers to appear in the local newspaper. ${ }^{81}$ 
Social-Movement Organizations: Skinhead and Neo-Nazi Groups The organizational basis for anti-minority violence was certainly present in Hoyerswerda, Rostock, and Riesa. A network of skinhead groups had become established in both East and West Germany during the late 1980s and had grown to about 6500 participants, 3000 of them in eastern Germany by 1991. ${ }^{82}$ These groups, consisting mainly of working-class teenage boys and increasingly under the influence of neo-Nazi organizations in this period, emphasized group loyalty, hostility toward the adult society, and violence against relatively weak groups, especially foreigners and leftists. The network of skinhead groups in Hoyerswerda was stronger than in most places in Saxony. The instigators of violence included a hard core of about thirty youths who used neo-Nazi symbols and slogans and were prone to violence, and another twenty sympathizers who were friends of hard core members. ${ }^{83}$ In Rostock, too, a large group of local skinheads and right-wing youth were involved in the riots. Moreover, on the second night of rioting, skinheads and neoNazis came to Rostock from other cities in Germany; they brought hard-core leadership and aggressive tactics, such as setting cars on fire to create barricades. ${ }^{84}$

Nonetheless, the Riesa case shows that organized and active perpetrators are not sufficient to produce anti-minority riots or significant anti-minority violence. Although Riesa skinheads formed a relatively large group and were at least as criminally active as their counterparts in Hoyerswerda (with 11 skinhead crimes against all targets reported over a 15-month period in Riesa compared with eight in Hoyerswerda), most of the Riesa skinheads' actions were attacks on leftist youth, or train and bus stations. ${ }^{85}$

\section{Conclusions: Immigration, Democratization, and Anti-Minority Riots}


In the early 1990s, eastern Germany was characterized by a transition to democracy, immigration, and a series of anti-foreigner riots. Hence analyzing this setting can provide insight into the processes which link both recent immigration and transitions away from authoritarian rule to anti-minority riots. The evidence presented here is that local political processes were the main causes of the eastern German riots, not ethnic competition or national opportunities. Inmigration by ethnic minorities led to riots in those localities where cultural conflicts were heightened by certain housing practices, where residents' participation was mischanneled, where local opportunities for anti-minority politics were provided, and where social-movement organizations mobilized.

In eastern Germany, the local processes which linked migration to riots were made much more likely by German unification, which involved rapid, chaotic transitions to both representative democracy and a market economy. These transitions created many major tasks and problems simultaneously, such as economic privatization and the reconstruction of public administration. Distracted by these matters, many state and local officials failed to respond effectively to the conflicts between Germans and foreign minorities, which would have required housing foreigners carefully, creating channels for nonviolent participation, and decisively policing the skinhead groups. However, as the Riesa case illustrates, many local and state officials in eastern Germany did respond effectively, which shows that the political failures were at the subnational level and not only the national level. ${ }^{86}$

Where attempts to extend democratic rights are accompanied by the collapse of state authority over an ethnically diverse population, anti-minority riots often result. For example, 
anti-Jewish pogroms in Odessa after the 1905 October Manifesto in Russia, anti-Muslim riots in India before Independence, and assaults on Romas' houses after the fall of communism in Romania fit this pattern. ${ }^{87}$ The local political processes identified in the eastern German cases may be important links between democratization and riots in other cases, too, though not necessarily the only links. That is, if a transition to democracy occurs in the context of longsuppressed cultural conflicts, then the sudden granting of civil liberties for anti-minority groups, combined with delays in creating nonviolent channels and developing adequate police forces, may cause riots.

Even where representative democracy is established, migration and cultural conflicts often precede anti-minority riots. For example, anti-black riots in northern U.S. cities before World War II, riots against West Indians and South Asians in Britain from the late '40s to mid-60s, and anti-Italian and anti-Turk riots in the Netherlands in the 1960s and '70s all occurred relatively soon after significant numbers of the minority group had arrived. Moreover, in those three countries, there is evidence that riots grew out of cultural conflicts between the long-time residents and the newcomers, over matters such as the use of knives in fights, sexual jealousies, and prostitution. The practice of housing ethnic minorities in hostels made riots especially likely since hostels concentrate the behaviors which the dominant group finds threatening and also make the minority group more vulnerable to large-scale attack. ${ }^{88}$

Are anti-minority riots a transient phenomenon? Husbands argues that the importance of cultural conflicts explains why anti-minority riots are often limited to the early, "immature" phase of ethnic relations, and are then replaced in later phases by small-scale racist violence (undertaken by the dominant group) and commodity riots (by the subordinate group). ${ }^{89}$ There are 
four main reasons why anti-minority rioting tend to decline after the initial phase of majorityminority contact; all of these have operated to large though varying degrees in the industrialized democracies and can account for the apparent end of anti-minority rioting there. First, the minority and majority groups have gained experience with each other, in residential areas and in workplaces, so that cultural differences are hidden, ignored, or recognized as banal rather than becoming fuel for great fears and wild rumors. Second, political elites often have reacted to riots by creating nonviolent channels for conflicts between dominant and minority ethnic groups, and by avoiding creating opportunities for anti-minority groups. Similarly, police often have become better prepared to prevent riots. Third, apparent opportunities for removing ethnic minorities have become less available than when immigrants were first arriving. In West European countries and in most U.S. cities, the sheer size and long presence of minority populations make demands for removing them less plausible than at the onset of migration; growth in the minorities' social and civil rights has also dampened their enemies' prospects.

The fourth reason is paradoxical. In many countries, far-right parties have become electorally successful by making anti-immigrant appeals and eschewing violence, or else mainstream parties have become more willing to sound anti-minority themes. ${ }^{90}$ In either case, when parties mobilize against immigrants, this may help to channel anti-minority sentiments into electoral politics and away from violence, even though at the same time it heightens those sentiments. $^{91}$

Nonetheless, anti-minority rioting does not necessarily cease in representative democracies, as the experience of contemporary India shows. The four processes just sketched are contingent on many other developments. Where migration of ethnic groups to new areas 
continues (even on a local or regional scale), where minorities remain socially unintegrated, where channels for nonviolent participation remain weak, where mainstream politicians choose to openly encourage violence, where nationalist parties promote violence instead of a purely electoral strategy, where international borders are in dispute, and where policing breaks down, anti-minority riots will be more likely. 


\section{Notes}

1. An earlier version was presented at the German Studies Association Conference in September 1997 and to the Workshop on Contentious Politics at Columbia University in October 1997. For help in gaining access to information, I would like to thank Stefanie Würtz, the archivists at the Stadtarchiv Hoyerswerda, the Sächsische Zeitung in Dresden, and the Ostsee Zeitung in Rostock, and those whom I interviewed. For comments and conversations, I would like to thank Werner Bergmann, Richard Deeg, Jack Hammond, Michael Hanagan, Jeffrey Herf, Christopher Husbands, John Krinsky, Roy Licklider, David S. Meyer, Francesca Polletta, Dieter Rucht, Naren Subramanian, Damir Skenderovic, John Skrentny, Charles Tilly, Helmut Willems, and two anonymous reviewers for this journal. The research for this article was supported by Award Numbers 665523 and 668538 from the Research Foundation, City University of New York, and by Eugene Lang and Ruth G. Weintraub Faculty Development Awards from Hunter College.

2. For examples of ideological explanations, see Panikos Panayi, "Racial Violence in the New Germany, 1990-93," Contemporary European History 3 (1994), 265-87, at 280-85; Gert Krell, Hans Nicklas, and Anne Ostermann, "Immigration, Asylum, and Anti-Foreigner Violence in Germany," Journal of Peace Research 33, 2 (1996), 153-70; Asgharali Engineer, Communalism and Communal Violence in India (Delhi: Ajanta, 1989), 26-36. For explanations based on inequality and competition, see e.g. Wilhelm Heitmeyer, "Das Desintegrationstheorem," in idem., ed., Das Gewalt-Dilemma (Frankfurt: Suhrkamp, 1994), 29-72, at 45-46; Susan Olzak, The Dynamics of Ethnic Competition and Conflict (Stanford, Calif.: Stanford University Press, 1992); Subho Basu, "Strikes and 'Communal' Riots in Calcutta in the 1890s," Modern Asian Studies 32 (1998), 949-83. For political-entrepreneurship explanations, see e.g. Ruud Koopmans, "Explaining the Rise of Racist and Extreme-Right Violence in Western Europe," European Journal of Political Research 30 (December 1996), 185-216, at 200-06; Stanley Tambiah, Leveling Crowds (Berkeley, Calif.: University of California Press, 1996), 224-30, 260-65.

3. For a similar argument, see Rogers Brubaker and David Laitin, "Ethnic and Nationalist Violence," Annual Review of Sociology 24 (1998), 423-58.

4. Anti-minority riots include events where the subordinate group fights back to a greater or lesser degree, but exclude those where only the subordinate group engages in sustained attacks. For more specifics on size, see note 8 below.

5. $\quad$ Frank Esser and Hans Brosius, "Television as Arsonist?" European Journal of Communication 11 (1996), 235-60; Ruud Koopmans, "Asyl: Die Karriere eines politischen Konflikts," in Wolfgang van den Daele and Friedhelm Neidhardt, eds., Kommunikation und 
Entscheidung (Berlin: Sigma, 1996), 167-92.

6. Ashutosh Varshney, "Postmodernism, Civic Engagement, and Ethnic Conflict," Comparative Politics 30 (October 1997), 1-20, at 2.

7. Author's estimate from Koopmans, "Explaining the Rise," 190, and Jens Alber, "Zur Erklärung fremdenfeindlicher Gewalt in Deutschland," in Ekkehard Mochmann and Uta Gerhardt, eds., Gewalt in Deutschland (Munich: Oldenbourg, 1995), 39-77, at 42-43.

8. Partei des demokratischen Sozialismus, ed., Neofaschistische Gewalt und Straftaten in der BRD, 1985-1995 (Bonn: idem., 1995). I defined major riots as involving at least 500 participants, or at least 100 on two consecutive days, and were identified from my analyses of die tageszeitung, cd-rom edition (1986-1997); for details, see Roger Karapin, "Major Anti-Minority Riots and National Legislative Campaigns against Immigrants in Britain and Germany," in Ruud Koopmans and Paul Statham, eds., Challenging the Politics of Ethnic Relations in Europe (New York: Oxford University Press, 2000), 312-47.

9. $\quad$ Manfred Kuechler, "Germans and 'Others' ?", German Politics 3 (April 1994), 47-74, at 64; Alber, 70-74.

10. Helmut Willems, et al., Fremdenfeindliche Gewalt (Opladen: Leske und Budrich, 1993), 40$41,44,50-51$.

11. For example, see Olzak, 24-47; Albon Man, "Labor Competition and the New York Draft Riots of 1863," The Journal of Negro History 36 (October 1951); Surangan Das, Communal Riots in Bengal, 1905-1947 (Delhi: Oxford University Press, 1991).

12. Robert E. Park, Race and Culture (Glencoe, Ill.: Free Press, 1950), 236-39.

13. Christopher Husbands, "The Dynamics of Racial Exclusion and Expulsion," in European Journal of Political Research 16 (1988), 701-20, at 706; "Racial Attacks," in Tony Kushner and Kenneth Lunn, eds., Traditions of Intolerance (Manchester: Manchester University Press, 1989), 91-115, at 96.

14. Allen Grimshaw, "Three Cases of Racial Violence in the United States," in idem., ed., Racial 
Violence in the United States (Chicago: Aldine, 1969), 105-15, at 105.

15. Clark McPhail, The Myth of the Madding Crowd (New York: Aldine de Gruyter, 1991).

16. William Gamson, The Strategy of Social Protest, 2nd ed. (Homewood, Ill.: Dorsey Press, 1990), 14-18.

17. Charles Tilly, From Mobilization to Revolution (New York: Random House, 1978); Sidney Tarrow, Power in Movement (New York: Cambridge University Press, 1994).

18. Tilly, 100 .

19. For anti-minority riots, see e.g. Morris Janowitz, "Patterns of Collective Racial Violence," in Hugh Graham and Ted Gurr, eds., Violence in America (New York: Praeger, 1969), 412-43, at 415-16; Grimshaw, "Actions of Police and Military in American Race Riots," in idem., Racial Violence, $269-87$.

20. Ralph Turner, "Race Riots Past and Present," Symbolic Interaction 17 (1994), 309-24, at 313; Neil Smelser, The Theory of Collective Behavior (New York: Free Press, 1963), 236-40; Helmut Willems, "Gewalt gegen Fremde," in Hans Peter Nolting, et al., Aggression und Gewalt (Stuttgart: Kohlhammer, 1993), 161-79, at 173.

21. Tilly, 133.

22. For example, Koopmans, "Explaining the Rise," 202-04; Graeme Atkinson, "Germany," in Tore Björgo and Rob Witte, Racist Violence in Europe (New York: St. Martin's, 1993), 154-66, at 160-61; Karl-Otto Richter and Bernhard Schmidtbauer, "Zur Akzeptanz von Asylbewerbern in Rostock-Stadt," Aus Politik und Zeitgeschichte 1993, No. 2-3, 44-54, at 51-52; Willems, Fremdenfeindliche Gewalt, 225-26.

23. See e.g. Varshney, 12; Paul Brass, "Introduction," in 서em., ed., $\underline{\text { Riots and Pogroms }}$ (New York: NYU Press, 1996), 1-55, at 12-13.

24. Rob Witte, Racist Violence and the State (New York: Longman, 1996), 5-6; Roger Karapin, 
"The Politics of Immigration Control in Britain and Germany," Comparative Politics 31 (July 1999), 423-44.

25. In Germany, police are under the authority of state governments and are often responsive to elected representatives at the county and city levels.

26. Turner, 315-16.

27. John D. McCarthy and Mayer Zald, "Resource Mobilization and Social Movements," American Journal of Sociology 82 (1977), 1212-41.

28. Mancur Olson, The Logic of Collective Action (Cambridge, Mass.: Harvard University Press, 1965), 53-65.

29. Willems, Fremdenfeindliche Gewalt, 191-93; Klaus Farin and Eberhard Seidel-Pielen, Skinheads (Munich: C.H. Beck, 1993).

30. Ralph Turner and Lewis Killian, Collective Behavior (Englewood Cliffs, N.J.: Prentice-Hall, 1957), 110; Robert Weinberg, "Anti-Jewish Violence and Revolution in Late Imperial Russia," in Brass, ed., Riots and Pogroms, 56-88, at 61; Edward Pilkington, Beyond the Mother Country (London: I.B. Taurus, 1988), 101-02, 106-18.

31. Hence I will use the terms "foreigner" and "ethnic minority" as synonyms for "immigrants" when discussing German cases.

32. Data from Statistisches Bundesamt, Federal Ministry of the Interior, and Statistisches Jahrbuch Deutscher Gemeinden (1992), 492.

33. Daniel Kanstroom, "Wer sind wir wieder? Laws of Asylum, Immigration, and Citizenship in the Struggle for the Soul of the New Germany," Yale Journal of International Law 18 (Winter 1993), 155-211.

34. Bundesministerium des Innern, Verfassungsschutzbericht 1991 (Bonn: idem., 1992), 76;

Verfassungsschutzbericht 1993 (Bonn: idem., 1994), 79-80; author's calculations. 
35. Karapin, "Major Anti-Minority Riots," 321.

36. Bundesministerium des Innern, Verfassungsschutzbericht 1991, 76.

37. Author's analysis of attacks during January-December 1991 and August-November 1992 reported in die tageszeitung and Partei des demokratischen Sozialismus, ed., Über den schonenden Umgang der Bundesregierung mit dem Rechtsextremismus, Teil 4 (Bonn: idem., 1993).

38. Hoyerswerda: county population 100,900; largest city 62,400 residents; foreign population 799 (January 1992) or 0.8\% of total; 230 asylum seekers in 1991; official unemployment 8.1\% (September 1991); unofficial unemployment, including those on "short hours," 23.4\% (Summer 1991). Riesa: county population 89,000 ; largest city 44,400 ; foreign population 892 or $1.0 \%$; 260 asylum seekers; official unemployment $8.3 \%$; unofficial unemployment $23.0 \%$ (same dates as for Hoyerswerda). Sources: Bundesforschungsanstalt für Landeskunde und Raumordnung, ed., Laufende Raumbeobachtung: Aktuelle Daten zur Entwicklung der Städte, Kreise, und Gemeinden, 1992-93 (Bonn: idem., 1995); foreign population data provided by Statistisches Landesamt des Freistaates Sachsen; unemployment rates are author's calculations from Sächsische Zeitung, Hoyerswerda edition (hereafter $\underline{\mathrm{SZH}}$ ), 8 August and 7 September 1991, Wochenblatt 11 October 1991, Sächsische Zeitung, Riesa edition (hereafter SZR), 9 July and 10 October 1991; asylum seekers from $\underline{\text { Sächsische Zeitung. }}$

39. Data from: Statistisches Landesamt Sachsen; the Zentrale Ausländerbehörde in Saxony; Staatsministerium des Innern, Saxony, Verfassungsschutzbericht 1993 (Dresden: idem., n.d.), 21; and a very helpful interview with Bernd Wagner, Berlin, 14 August 1997. Low-violence communities were defined as those lacking reported attacks (see previous note) against foreigners' housing which involved attempted arson, storming or besieging the building, injuries, or the flight or evacuation of the residents.

40. Paul Hockenos, Free to Hate (New York: Routledge, 1993), 24-25.

41. $\underline{\text { SZR }}, 21$ February 1991; other data supplied by Statistisches Landesamt Sachsen. Resettlers were not housed in Hoyerswerda until 1993.

42. All accounts of the 1991 Hoyerswerda riots are from $\underline{\mathrm{SZH}}, \underline{\text { Lausitzer Rundschau }}$ (Hoyerswerda edition, hereafter LR), Hoyerswerdaer Wochenblatt (hereafter $\underline{\mathrm{HW}})$, Hoyerwerdaer Wochenspiegel, BILD (Dresden edition), and the Dresdner Morgenpost, 19-27 September 1991. 
43. Frankfurter Allgemeine Zeitung, 24 September 1991.

44. $\underline{\text { SZR, }} 14$ September 1992.

45. Irwin Collier, "German Economic Integration," in Michael Huelshoff, Andrei Markovits, and Simon Reich, eds., From Bundesrepublik to Deutschland (Ann Arbor: University of Michigan Press, 1993), 93-113, at 97; Thomas Baylis, "Transforming the East German economy," in op cit., 77-92, at 83-89; author's calculation.

46. Similar to my findings, a county-level cross-sectional multivariate analysis showed basically no relation between unemployment and attacks on foreigners; see Alan Krueger and Jörn-Steffen Pischke, "A Statistical Analysis of Crime against Foreigners in Unified Germany," Journal of Human Resources 32 (Winter 1997), 182-209.

47. $\underline{\mathrm{SZH}}, 7-8$ September 1991; $\underline{\mathrm{HW}}, 16$ August, 13 September, 11 October, 13 December 1991; Bundesanstalt für Arbeit, ed., Arbeitsstatistik 1992, Jahreszahlen (Nürnberg: idem., 1993), 263.

48. Rainer Joedecke, "Willkommen in Hoyerswerda," Kursbuch 107 (1992), 69-108, at 77.

49. Kanstroom, p. 197 \& n. 337; $\underline{\text { HW}, ~} 26$ July 1991.

50. Foreign population share also declined in the county; data supplied by Ordnungsamt der Stadt Hoyerswerda, July 1997 (author's calculations).

51. $\underline{\text { SZR, }} 10$ April 1991.

52. Interviews with Martin Schmidt, Hoyerswerda, 31 July and 1 August 1997; Joedecke, 76-77; Hockenos, 24.

53. $\underline{\text { HW}}, 26$ July 1991; $\underline{\text { SZH}}, 19$ July, 29 August 1991; $\underline{\text { LR, }} 29$ August 1991. 
54. Patrick Ireland, "Socialism, Unification Policy, and the Rise of Racism in Eastern Germany," International Migration Review 31 (Fall 1997), 541-68, at 548-49.

55. Ursula Münch, Asylpolitik in der Bundesrepublik Deutschland: Entwicklung und Alternativen, 2nd ed. (Opladen: Leske und Budrich, 1993); Ursula Linke and Klaus Ness, "Von der GST zur ZAST," in Ralf Ludwig, Klaus Ness, and Muzaffer Perik, eds., Fluchtpunkt Deutschland (Berlin: Schüren, 1992), 124-36.

56. Ostsee Zeitung, 18-19 June 1992; Norddeutsche Neuste Nachrichten (Rostock edition), 18 June, 14 July 1992.

57. Norddeutsche Neuste Nachrichten, 19 August 1992; Stefanie Würtz, "Rostock Chronologie," unpublished manuscript, 1993.

58. $\quad \underline{\text { SZR }}$, 26 July, 18 December 1991, 8 February 1992; BILD, 21 December 1992.

59. $\quad \underline{\text { SZR }}, 28$ May 1993.

60. $\underline{\mathrm{SZH}}$, passim.

61. Interview with Schmidt; $\underline{\mathrm{SZH}}$ 16, 29 August 1991; $\underline{\mathrm{LR}}, 29$ August 1991.

62. $\underline{\mathrm{HW}}$ and Dresdner Morgenpost, 20 September 1991; $\underline{\mathrm{SZH}}$ and die tageszeitung (hereafter taz), 21 September 1991; Junge Welt and $\underline{\text { SZH, }} 23$ September 1991.

63. $\underline{\mathrm{SZH}}, 5$ October 1990, 29 August 1991. More than a dozen attacks against foreigners were reported in the week prior to the riots; $\underline{\mathrm{SZH}}, 19$ September 1991.

64. taz, 23 September 1991.

65. taz, 26 August 1992.

66. Willems, "Gewalt," 175. 
67. $\underline{\mathrm{SZH}}, 8,28$ June, 18, 21, 23 September 1991.

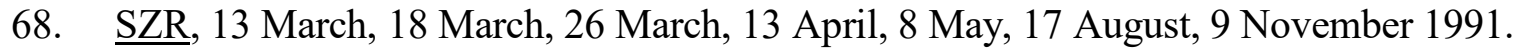

69. $\quad \underline{\text { SZR }}, 13$ April 1991, 29 August, 14 September 1992.

70. Landeskriminalamt Sachsen, Polizeiliche Kriminalstatistik Freistaat Sachen 1992 (Dresden,

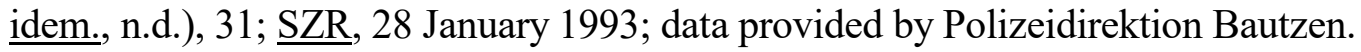

71. $\underline{\text { SZR }}, 28$ January 1993.

72. $\underline{\text { SZR }}, 13$ March 1991.

73. Eight in Riesa versus three in Hoyerswerda ( $\underline{\mathrm{SZR}}$ and $\underline{\mathrm{SZH}}$, passim).

74. Campaigns were measured by articles in taz, which ranged from 1 to 104 per month during 1990-93, with five separate peaks of over 20 articles per month. I judged that a campaign existed prior to a riot if leading politicians were involved and at least 20 articles were published during the previous 30 days. By contrast, the 60 days before Hoyerswerda saw only 5 articles per month, and the 60 days before Rostock saw only 11 articles per month. For details and a graphical presentation, see Karapin, "Major Anti-Minority Riots," 320, 330-37.

75. Forschungsgruppe Wahlen data (open-ended question) from Eike Hennig, "Deutschland von Rechts," Wochenschau für politische Erziehung, Sozial- und Gemeinschaftskunde 42 (NovemberDecember 1991), 211-39, at 212; Dieter Roth, "Was bewegt die Wähler?" Aus Politik und Zeitgeschichte (18 March 1994), 3-13, at 6-7.

76. taz, 7 May 1990; the lull was indicated by a steady trickle of about two articles per month for the previous twelve months.

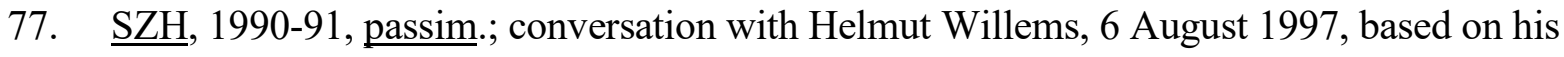
field research. 
78. $\underline{\text { SZH, }} 29$ August 1991.

79. Ostsee Zeitung, 25 June 1992.

80. $\underline{\mathrm{SZH}}, 6$ and 19 July 1991.

81. $\underline{\text { SZR }} 7$ March 1991, 15 October 1992, 13 February 1993 for meetings; $\underline{\text { SZR }}, 23$ January, 21 February, 7 March 1991 for articles.

82. Bundesministerium des Innern, Verfassungsschutzbericht 1991, 91.

83. Interviews with Schmidt, Wagner, and Friedhart Vogel, Hoyerswerda, 29 July 1997; sources cited in n. 42.

84. Würtz.

85. $\underline{\text { SZR }}$ and $\underline{\mathrm{SZH}}$, October 1991 through December 1992.

86. For a focus on national-level policy failures, see Ireland, 550-62.

87. Weinberg; Ian Copland, "Communalism in Princely India," Modern Asian Studies 22 (1988), 783-814, at 813; Laszlo Kürti, "Racism, the Extreme Right, and Anti-Gypsy Sentiments in EastCentral Europe," in Jean-Yves Camus, Extremism in Europe (Paris: editions de l'aube, 1998), 42144, at 426.

88. Grimshaw, "Three Cases," 106, 108, 110, 112; "Factors Contributing to Color Violence in the United States and Britain," in idem., Racial Violence, 254-69, at 258, 263; James Wickenden, Colour in Britain (London: Oxford University Press, 1958); Dilip Hiro, Black British, White

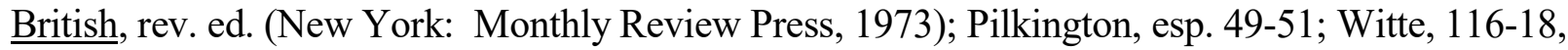
122-23.

89. Husbands, "Racial Attacks," 96; see also Janowitz, 415-18; Panayi, 275-77. 
90. Hans-Georg Betz, Radical Right-Wing Populism in Western Europe (New York: St.

Martin's Press, 1994); Herbert Kitschelt, The Radical Right in Western Europe (Ann Arbor, Mich.: University of Michigan Press, 1995).

91. Koopmans, "Explaining the Rise," 206-09. 